\title{
EFFECTS OF COCOA BEAN SHELL ON THE PERFORMANCE, BLOOD INDICES AND ORGAN CHARACTERISTICS OF COCKERELS
}

\author{
ADEYINA, A.O., ANNONGU A.A. and AWE O. \\ Department of Animal Production,University of Ilorin \\ e-mail: aadeyina@yahoo.com
}

\begin{abstract}
One hundred and five Nera cockerels were randomly assigned to 5 isonitrogenous and isocaloric dietary treatments of 0\%, 5\% 10\%, 15\% and $20 \%$ Cocoa Bean Shell(CBS) in a complete randomized design experiments. Each dietary treatment was replicated three times for an experimental period of 18 weeks (3-8 weeks of age, starter diet, 9-20 weeks of age, grower diet). At the starter phase, cockerel chicks fed $10 \%$ CBS based diet had the lowest feed intake and the highest weight $(P<0.05)$. Theobromine intake increased significantly $(P<0.05)$ with $C B S$ inclusions while feed to gain ratio was not significant $(P>0.05)$. In the grower phase, cockerels fed CBS based diet had significantly $(P<0.05)$ low feed intake compared to those on control diet. Feed: gain ratio was significantly $(P<0.05)$ high among birds fed CBS based diets at inclusion levels of 15 and $20 \%$ respectively at the grower phase. Carcass characteristics showed that dressing percentage was similar $(P>0.05)$ for cockerels fed $0 \%$ and $5 \%$ CBS based diets while gizzards weight significantly $(P<0.05)$ increased with increase in $C B S$ inclusion. Birds fed CBS based diets had low PCV, Hb and high WBC compared with the control. It was concluded that cocoa bean shell could be used in cockerels diet up top $10 \%$ inclusion level.
\end{abstract}

Key words: cocoa bean shell, performance blood indices, cockerels.

\section{INTRODUCTION}

The increase in the cost of conventional feed ingredients has stimulated the search for non-conventional feedstuffs for use in the intensive animal production system. Cocoa Bean Shell (CBS) is one of such alternative feed sources with good nutritional potentials. It is a waste from cocoa processing industries with no constraints to its availability (Shobamiwa, et al, 1999). Reports showed that CBS contained $14.5 \%$ crude protein and $18.3 \%$ crude fibre (Abiola and Tewe, 1991). 
The use of CBS in poultry feed was investigated in laying hens (Shobamiwa et al, 1999), broiler and Peckin ducks (Yeong et al, 1989) and has been discouraged even at low inclusion level of 5\%. This is due to its theobromine content which is the inherent toxic and antinutrotional factor (Yoeng et al, 1989). However, there is paucity of information in the use of cocoa bean shell in cockerels production. Cockerels have idiosyncratic advantage of hardiness and high survival rate over other classes of birds (Ogbona and Adebowale, 1993) which could make them tolerant to poor quality feedstuffs. This study was conducted to investigate the performance, blood indices and organ characteristics of cockerels fed CBS based diets during the starter and grower phases.

\section{MATERIALS AND METHODS}

\section{Location and Site}

Cocoa bean shell used for this experiment was collected from Stamack Industries Limited, Ondo, Nigeria and the experiment was carried out at the Animal Pavilion, University of Ilorin.

\section{Experimental Procedure}

One hundred and five, two weeks old cockerel chicks of comparable body weight were selected from One hundred and twenty naira black cockerels. The birds were randomly distributed into five isonitrogenous and isocaloric dietary treatments (NRC, 1994) with cocoa bean shell (CBS) included in the diets at 0. 5, 10, 15 and 20\% respectively (Table 2 and 3 ). The birds were placed in electrically heated metabolic cage using a completely randomized design. Each of the dietary treatment had 3 replicates with 7 birds per replicate. The feed and water were offered ad-libitum for 18 weeks feeding period. Feed intake, body weight gain and feed: gain ratio were recorded.

\section{Haematological Studies}

At the end of the feeding trial, 2 birds per replicate ( 6 birds per treatment) were selected and sacrificed by cutting through the jugular vein. Blood samples for haematological determination were collected in EDTA treated bottles and the haematological indices were determined according to Onifade and Tewe (1993).

\section{Defeathering and Evisceration}

The carcasses were defeathered by immersing in hot water $\left(80^{\circ} \mathrm{C}\right)$ for one minute and the feathers were plucked manually. The viscera organs were removed through a cut from the vent, subsequently to determine the eviscerated weight. The head and the two shanks were also removed. The dressing percentage was then recorded as follows: 


$$
\text { Dressing percentage }=\frac{\text { Weight of empty carcass } \mathrm{x} 100}{\text { Weight at slaughter }}
$$

The weight of abdominal fat as well as the gizzard were also taken.

\section{Chemical Analysis}

Proximate composition and theobromine content of CBS were determined according to AOAC (1990) and Odunsi et al (1999). The metabolizable energy of CBS $(2461 \mathrm{kcal} / \mathrm{kg}$ ) was calculated as follows: $37 \%$ crude protein $+81.8 \%$ crude fat $+35 \%$ Nitrogen free extract (Pauzengia, 1985) and the nutrient values of other ingredients were obtained from feed nutrients table (Aduku, 1993).

\section{Statistical Analysis}

Data obtained were subjected to statistical Analysis of Variance using SPSS version II and treatment means tested by Duncan multiple range test (Duncan,1985).

\section{RESULTS}

The results of growth performance are presented in (Table 4). In the starter phase feed intake of birds fed CBS based diets was significantly $(\mathrm{P}<0.05)$ lower than that of the control. Birds fed 20\% CBS based diet had the lowest feed intake. Body weight gain were comparable $(\mathrm{P}>0.05)$ for birds fed 0\% 5\% and 10\% CBS based diets but significantly lower $(\mathrm{P}<0.05)$ for birds fed $15 \%$ and $20 \%$ dietary inclusion levels of CBS respectively. Theobromine intake increased significantly $(\mathrm{P}<0.05)$ with CBS inclusion in the diets. Feed gain ratio was not influenced $(\mathrm{P}>0.05)$ by $\mathrm{CBS}$ inclusion levels in diets.

In the grower phase, birds fed 5\% $15 \%$ and 20\% CBS based diets had comparable $(\mathrm{P}>0.05)$ feed intake which was significantly $(\mathrm{P}<0.05)$ higher than feed intake of birds fed $10 \%$ CBS diets. However, weight gain of birds fed 10\% CBS based diet at the grower phase was significantly $(\mathrm{P}<0.05)$ higher than that of birds on other diets. Feed to gain ratio was significantly $(\mathrm{P}<0.05)$ lower for birds fed $10 \%$ CBS based diet than birds given the control and other dietary levels of CBS.

The data on carcass characteristics is shown in Table 5. The abdominal fat of birds fed CBS based diet was significantly $(\mathrm{P}<0.05)$ lower than those on the control. Gizzard weight of birds increased $(\mathrm{P}<0.05)$ with increase in CBS inclusion. Birds fed $10 \%$ CBS based diet had significantly $(\mathrm{P}<0.05)$ higher dressing percentage compared with birds fed control and other CBS based diets. Birds fed with control had significantly $(\mathrm{P}<0.05)$ higher $\mathrm{PCV}$ value (Table 5$)$ which decreased with increase in inclusion level of CBS in the diets. WBC value was significantly $(\mathrm{P}<0.05)$ higher for birds fed CBS based diets than birds given the controls diet. 


\section{DISCUSSION}

The decrease in feed consumption at the starter and grower phases is in consonance with Odunsi and Longe (1995) who reported reduced feed intake when broilers were fed CBS based diet. However, cockerels generally have high survival rate (Ogbona and Adewale, 1993) and an advantageous tendency when maintained on low quality feed than broilers. The reduced feed intake observed for bird fed higher levels of CBS could have resulted from the inability of the birds to tolerate CBS due to its high theobromine content (Yeong et al, 1989). Decreased body weight gain observed in birds fed higher levels of CBS might be as a result of poor nutrients absorption (Yeong et al, 1989), unavailability of nutrients and impaired digestive and metabolic activities (Egbewande and Olorede, 2003).

The low abdominal fat recorded for birds fed CBS based diet might have been caused by inherent theobromine in the diets. Hutagalung and Chang (1978) reported a reduction in back fat thickness when cocoa pod husks $(\mathrm{CPH})$ containing theobromine was fed to pigs. Theobromine is a phosphodiesterase inhibitor via cyclic adenosine 3' 5'monophosphate (cAMP). The cAMP triggers the production of sensitive lipase and hydrolysis of fat. The function of phosphodiesterase is to reduce the hydrolysis of fat and causes the animal to loss weight (Guyton, 1969) and possibly abdominal fat. Theobromine through the action of cAMP brings about lipolysis (Joseph, 1954). The enlarged gizzard of birds fed CBS based diets could be the results of functional adaptability of the GIT to the CBS based diet (Yeong et al, 1989).

Indirect nutritional assessment revealed that haematologial indices depicted similarities with inclusion of CBS in the diets. They are still within the normal range reported for chicken (Bolu and Olatunde, 2003). This implies that dietary treatment could be safe. The increase in WBC could be a reflection of the circumstances in the tissue for which sensibility varies from specie to specie as abnormal response to drugs and toxins (Merck, 1998). The inherent theobromine in the CBS based diet could have triggered the increase. Similar observation was recorded in rabbits fed CBS based diets (Adeyina et al, 2005). This trend of haematological indices among the experimental birds may be indicative of sub-clinical, clinical response or just a demonstration of immune competence (Onifade et al, 1999). The latter is more likely because there was no mortality recorded among the birds.

It can be concluded that CBS is a potential, non-conventional feed stuff which could be used in the diet of cockerels at $10 \%$ inclusion which is the level with the lowest feed: gain ratio. 
Table 1

Proximate Composition and Theobromine content of CBS

\begin{tabular}{l|c}
\hline \multicolumn{1}{c|}{ Nutrient } & $\%$ \\
\hline & \\
Dry matter & 89.10 \\
Crude protein & 14.60 \\
Ether extract & 3.5 \\
NFE & 46.7 \\
Crude fibre & 16.50 \\
Ash & 6.80 \\
Theobromine & 2.88 \\
\hline
\end{tabular}

Values are means of triplicate determinations

Table 2: Composition of Experimental Diets $(\mathrm{kg} / 100 \mathrm{~kg})$ during the Starter phase.

\begin{tabular}{l|l|l|l|l|l}
\hline \multicolumn{6}{c}{ Levels of CBS (\%) } \\
Ingredients & $\mathbf{0}$ & $\mathbf{5}$ & $\mathbf{1 0}$ & $\mathbf{1 5}$ & $\mathbf{2 0}$ \\
\cline { 2 - 6 } & 43.0 & 55.0 & 53.0 & 51.0 & 48.0 \\
Maize & 38.0 & 16.0 & 13.0 & 11.0 & 7.0 \\
PKC & 13.0 & 18.0 & 18.0 & 17.0 & 17.0 \\
GNC & 2.0 & 2.0 & 2.0 & 2.0 & 2.0 \\
Fishmeal & 2.5 & 2.5 & 2.5 & 2.5 & 2.5 \\
Bone meal & 1.0 & 1.0 & 1.0 & 1.0 & 1.0 \\
Oyster shell & 0.25 & 0.25 & 0.25 & 0.25 & 0.25 \\
Vitamin premix & 0.25 & 0.25 & 0.25 & 0.25 & 0.25 \\
Salt & 100.00 & 100.00 & 100.00 & 100.00 & 100.00 \\
\hline Calculated analysis & 18.51 & 18.49 & 18.21 & 18.27 & 18.29 \\
\hline Crude protein (\%) & 2770 & 2768 & 2779 & 2773 & 2770 \\
ME (kcal/kg) &
\end{tabular}


Table 3: Composition of Experimental Diets (kg/100kg) during the Grower phase.

\begin{tabular}{l|l|l|l|l|l}
\hline \multirow{2}{*}{ Ingredients } & 0 & 5 & 10 & 15 & 20 \\
\cline { 2 - 6 } & & & & & \\
Maize & 47.0 & 55.0 & 53.0 & 52.0 & 48.0 \\
PKC & 38.0 & 24.0 & 21.0 & 19.0 & 16.0 \\
GNC & 9.0 & 10.0 & 10.0 & 10.0 & 10.0 \\
Fishmeal & 2.0 & 2.0 & 2.0 & 2.0 & 2.0 \\
Bone meal & 2.5 & 2.5 & 2.5 & 2.5 & 2.5 \\
Oyster shell & 1.0 & 1.0 & 1.0 & 1.0 & 1.0 \\
Vitamin premix & 0.25 & 0.25 & 0.25 & 0.25 & 0.25 \\
Salt & 0.25 & 0.25 & 0.25 & 0.25 & 0.25 \\
& 100.00 & 100.00 & 100.00 & 100.00 & 100.00 \\
\hline Calculated analysis & 16.39 & 16.35 & 16.33 & 16.49 & 16.38 \\
Crude protein (\%) & 2719 & 2752 & 2757 & 2753 & 2763 \\
ME (kcal/kg) & 279 &
\end{tabular}


Table 4: Effects of Levels of CBS on Growth Performance of Cockerels (starter and grower phases)

\begin{tabular}{c|c|c|c|c}
\hline $\begin{array}{c}\text { CBS \% (Starter } \\
\text { phase) }\end{array}$ & $\begin{array}{c}\text { Average feed } \\
\text { intake g/bird }\end{array}$ & $\begin{array}{c}\text { Average } \\
\text { weight g/bird }\end{array}$ & $\begin{array}{c}\text { Feed } \\
\text { grain }\end{array}$ & $\begin{array}{c}\text { Theobromine } \\
\text { intake g/bird }\end{array}$ \\
\hline & $1135.36^{\mathrm{a}}$ & $284.40^{\mathrm{ab}}$ & 3.99 & $0.00^{\mathrm{a}}$ \\
5 & $1124.20^{\mathrm{b}}$ & $282.24^{\mathrm{b}}$ & 3.96 & $1.619^{\mathrm{d}}$ \\
10 & $1067.36^{\mathrm{c}}$ & $290.76^{\mathrm{a}}$ & 3.67 & $3.269^{\mathrm{c}}$ \\
15 & $1055.04^{\mathrm{c}}$ & $258.88^{\mathrm{c}}$ & 4.08 & $4.558^{\mathrm{b}}$ \\
20 & $999.32^{\mathrm{d}}$ & $244.28^{\mathrm{d}}$ & 4.09 & $5.756^{\mathrm{a}}$ \\
SEM & 32.03 & 13.42 & 0.12 & 2.03 \\
\hline
\end{tabular}

\begin{tabular}{|c|c|c|c|c|}
\hline \multicolumn{5}{|c|}{ Grower phase } \\
\hline 0 & $7271.43^{\mathrm{a}}$ & $1465.28^{\mathrm{b}}$ & $4.96^{b}$ & 0.00 \\
\hline 5 & $7109.07^{\mathrm{b}}$ & $1467.37^{b}$ & $4.84^{b}$ & $10.237^{\mathrm{d}}$ \\
\hline 10 & $6866.67^{\mathrm{c}}$ & $1687.14^{\mathrm{a}}$ & $4.07^{\mathrm{c}}$ & $20.942^{c}$ \\
\hline 15 & $7007.16^{\mathrm{b}}$ & $1363.26^{c}$ & $5.14^{\mathrm{a}}$ & $30.270^{\mathrm{b}}$ \\
\hline 20 & $7015.06^{\mathrm{b}}$ & $1285.34^{\mathrm{d}}$ & $5.46^{\mathrm{a}}$ & $40.406^{\mathrm{a}}$ \\
\hline SEM & 105.16 & 101.45 & 0.42 & 5.97 \\
\hline
\end{tabular}

abcd: Values in the same column having different superscripts differ significantly $(\mathrm{P}<0.05)$

Table 5: Effects of Levels of CBS on Carcass characteristics of Cockerels

\begin{tabular}{l|c|c|c|c|c|c}
\hline & \multicolumn{5}{|c}{ CBS Inclusion levels (\%) } \\
\hline Parameters & 0 & 5 & 10 & 15 & $20^{\mathrm{c}}$ & SEM \\
& & & & & & \\
Abdominal fat & $1.80^{\mathrm{b}}$ & $0.11^{\mathrm{b}}$ & $0.01^{\mathrm{c}}$ & $0.02^{\mathrm{c}}$ & $0.01^{\mathrm{c}}$ & 0.36 \\
Dressing percentage & $66.48^{\mathrm{b}}$ & $66.15^{\mathrm{b}}$ & $69.25^{\mathrm{a}}$ & $64.83^{\mathrm{c}}$ & $64.00^{\mathrm{a}}$ & 1.05 \\
Gizzard weight & $2.65^{\mathrm{b}}$ & $2.87^{\mathrm{b}}$ & $3.01^{\mathrm{ab}}$ & $3.31^{\mathrm{a}}$ & 3.43 & 0.20 \\
\hline
\end{tabular}

abc: value in the same row having different superscripts differ significantly $(\mathrm{P}<0.05)$ 
Table 6: Effects of Levels of CBS on Heamatological indices of Cockerels

\begin{tabular}{l|c|c|c|c|c|c}
\hline & \multicolumn{6}{|c}{ CBS Inclusion levels (\%) } \\
\hline Parameters & 0 & 5 & 10 & 15 & 20 & SEM \\
& & & & & & \\
PCV \% & $23.67^{\mathrm{a}}$ & $21.33^{\mathrm{b}}$ & $18.33^{\mathrm{c}}$ & $20.67^{\mathrm{b}}$ & $17.33^{\mathrm{c}}$ & 1.20 \\
$\mathrm{RBC}\left(\mathrm{x} \mathrm{10} 0^{12 / \mathrm{L}}\right)$ & 4.03 & 3.80 & 3.30 & 3.30 & 3.37 & 0.20 \\
$\mathrm{WBC}\left(\mathrm{x} \mathrm{10} 0^{9 / \mathrm{L}}\right)$ & $8.87^{\mathrm{c}}$ & $9.50^{\mathrm{b}}$ & $10.17^{\mathrm{a}}$ & $9.50^{\mathrm{b}}$ & $10.53^{\mathrm{c}}$ & 0.44 \\
$\mathrm{Hb}(\mathrm{g} / \mathrm{dl})$ & $7.27^{\mathrm{a}}$ & $6.60^{\mathrm{a}}$ & $5.67^{\mathrm{b}}$ & $5.77^{\mathrm{b}}$ & $5.70^{\mathrm{b}}$ & 0.40 \\
\hline
\end{tabular}

abc: values within the same row having same superscripts are similar $(\mathrm{P}<0.05)$

\section{REFERENCES}

Abiola and Tewe (1991). Chemical Evaluation of cocoa by products. Trop. Agric (Trinidad) 68:335-336.

Adeyina, A.O. Apata D.F. and Olatunde O.A. (2005). Performance and physiological response of rabbits fed cocoa bean shell based diet. Nig. J. Pure and appl. Sci. 20:1767-1773.

Aduku, A.O. (1993). Tropical feedstuff analysis table. Department of Animal Production, Ahmadu Bello University, Zaria, Nigeria.

AOAC (1990). Official methods of analysis $\left(15^{\text {th }}\right.$ Edition). Association of official analyticalChemist Washington, D.C., USA.

Bolu, S.A. and Olatunde, A.A. (2003). Response of Broilers to different Sources of Vitamin C.J.Agric.Res. AndDev. 2:7-13.

Egbewande, O.O. and Olorede, B.R. (2003). Substitution of groundnut cake with mistletoe (Loranthus bengwensis) leaf meal in boiler diet. Proceedings ASAN $8^{\text {th }}$ Conf. Eds. Olatunji, E.A., Ayanwande, B.A., Shiawoya, E.L., Aremu, A. Minna, Nigeria, : 1-3.

Gomez,A.K. and Gomez, E.A. (1993). Statistical procedures for Agricultural Research. Wiley, New York.

Guyton, A.C., (1969). Textbook of Medical Physiology, $2^{\text {nd }}$ Ed. W.B. Saunders, Co., Philadelphia, : 162-164. 
Hutagalung, R.L. and Chang, C.L. (1978). Utilization of cocoa by product as animal feed. Proceeding of Int. conf. On cocoa and coconuts. P447-456. Kuala Lumpur: Incorporated society of Planters.

Joseph, R.D. (1954). Xanthine: Drill pharmacology in Medicine $4^{\text {th }}$ Edition. Varrotyler Co., London:53-549.

Merck Veterinary Manual (1998). Eight Edition. Merck and Co., Inc. Rahway U.S.A. . :2018-2019.

Odunsi, A.A. and Longe, O.G. (1995a). cocoa bean cake in poultry diet (1): Chemical composition and nutritive value of cocoa bean cake in pullet chick diets. J. Appl. Anim. Res. 7:91-98.

Odunsi, A.A. Shobamiwa, O. and Longe, G. (1999). Comparative Utilization of alkali treated and untreated cocoa bean cake in diet of egg type chicken. Trop. J. animal Sci. 2(1)63-68.

Ogbona, J.U. and Adewale, E.A. (1993). Effect of sun dried cassava peel meal as replacement and nutrient utilization of cockerels. Nig. Journal of Animal Prod. $.20: 1 \& 2$.

Onifade and Tewe (1993). Alternative tropical energy feed resources in rabbit diet. Growth performance, diets digestibility and blood composition. World Rabbit Sci. 1:17-24.

Onifade,A.A., Obiyan, R.I., Onipede, E.Adejumo, D.O.,Abu, O.A. and Babatunde, G.M.(1999). Assessment of effects of supplementing rabbit diet with a culture of saccharomytes cerevisiciae using growth performance, blood composition and clinical enzyme activities. Animal Feed Science and Technology. 77:25-32.

Pauzenga, U. (1985). Feeding parent stock. Zootechniocal international, December, :22-24.

Shobamiwa, O. Longe, O.G. and Odunsi, A.A. (1999). Utilization of Alkali treated cocoa husk in broiler finisher diet. Nig. Journal of Tree Crop Research, 3(1):1119.

Yeong, S.W., Lim, F. and Azizah, A. (1989). The nutritive value of cocoa bean shell for boilers and pekin ducks. MARDI, Res. J. 17(2):258-264. 